\title{
LUT
}

University

\section{Systematic study on sulfate removal from mining waters by electrocoagulation}

Mamelkina Maria A., Tuunila Ritva, Sillanpää Mika, Häkkinen Antti

This is a Author's accepted manuscript (AAM) version of a publication published by Elsevier

in Separation and Purification Technology

DOI: $10.1016 /$ j.seppur.2019.01.056

Copyright of the original publication: () 2019 Elsevier B.V.

Please cite the publication as follows:

Mamelkina, M.A., Tuunila, R., Sillanpää, M., Häkkinen, A. (2019). Systematic study on sulfate removal from mining waters by electrocoagulation. Separation and Purification Technology, vol. 216, pp. 43-50. DOI: 10.1016/j.seppur.2019.01.056

This is a parallel published version of an original publication. This version can differ from the original published article. 


\title{
Systematic study on sulfate removal from mining waters by electrocoagulation
}

\author{
Maria A. Mamelkinaa, Ritva Tuunila ${ }^{a}$, Mika Sillanpääb, Antti Häkkinena \\ a Lappeenranta-Lahti University of Technology, School of Engineering Science, 53850, \\ Lappeenranta, Finland \\ ${ }^{b}$ Lappeenranta-Lahti University of Technology, School of Engineering Science, 50130, Mikkeli, \\ Finland
}

Corresponding author: maria.mamelkina@lut.fi, PO Box 20 FI-53851 Lappeenranta Finland

\begin{abstract}
The mining industry is known to be a major producer of sulfate-rich waters that are harmful to aquatic systems, accelerate acid mine drainage formation and hinder the reuse and recycling of process water. In recent years, many treatment techniques have been studied and developed to treat sulfate-rich streams. One such technique, electrocoagulation (EC), was proposed as a possible alternative to conventional treatment technologies. Electrocoagulation has been used for the removal of nitrate, cyanide and toxic metals from mining waters, but the information about sulfate removal is scarce. In this paper, the results from a systematic study on sulfate removal by EC with iron electrodes applying a $3^{3}$-full factorial design are discussed. The results show the leading role of applied current on sulfate removal. In addition, the study concludes that the utilisation of iron electrodes was more efficient in terms of sulfate removal comparing to aluminium electrodes. The removal of sulfate was as high as $54 \%$ and $10 \%$ using iron and aluminium electrodes respectively. Under the studied experimental conditions, sulfate was proposed to be removed because of particle charge neutralisation and enmeshment of the studied anion in iron oxides and hydroxides.
\end{abstract}

Keywords: sulfate removal, design of experiments, mining waters, electrocoagulation, wastewater treatment

Highlights:

- EC-treatment enables the partial removal of sulfate from sulfate-rich waters

- Iron electrodes were proved to achieve a higher removal of sulfate

- Sulfate removal is due to its enmeshment in iron oxides and hydroxides

- Particle charge neutralisation is suggested as the possible sulfate removal mechanism

- Sulfate removal is a current and concentration dependent process 


\section{Introduction}

Mining waters are often heavily contaminated with anionic and cationic species. Among the most prevalent and harmful compounds are toxic metals [1] and anionic contaminants, such as sulfate, nitrate, chloride, cyanide and fluoride [2]. Concentrations of harmful contaminants are mine-specific, and it is thus difficult to assess the true scale of the environmental impact of mine water discharges accurately. However, it is essential to treat discharged wastewaters and bring the concentrations of harmful dissolved contaminants to acceptable discharge levels $[3,4]$. Another mining wastewater management concept is to reuse and recycle water within the process sections. Firstly, it makes mining operation more economically and environmentally feasible. Secondly, it allows for treating water only to a level suitable for a certain process rather than to an acceptable discharge level [5].

One of the most common anionic species present in mine wastewaters is sulfate as a final oxidation product of sulfuric minerals [6]. In addition, the use of chemicals, especially sulfuric acid, during the mining processes results in high sulfate concentration in mining waters. The sulfate concentration in mine waters may be from hundreds to several tens of thousands of milligrams per litre [1]. The effluent emanating from mineral excavation and manufacture contains a high concentration of sulfate ions, but acid mine drainage (AMD) tends to be the main source of sulfate at the mine site [7]. AMD is considered a natural process, but it is accelerated significantly with mining activities. The influence of AMD on the environment is the most severe in closed and abandoned mines, due to an increase of the water tables once pumping is stopped [8].

Requirements and restrictions on the quality of mining waters result in the limitation of discharge concentrations of several anionic compounds. Globally, the discharge limit for sulfate varies from $250 \mathrm{mg} / \mathrm{L}$ (USA) to $1,000 \mathrm{mg} / \mathrm{L}$ (Brazil, Chile) $[9,10]$. Currently, no general limit is set for the allowed amount of sulfate to be discharged in Finland, although some minespecific limits for certain mines have been already established and new regulation are expected in future [11]. High concentrations of sulfate result in a high toxicity of waters, serious pollution of natural water bodies and decrease of the reproduction of soils [12].

During recent decades, close attention has been paid to innovative processes enhancing the removal efficiency of contaminants, minimising chemical usage, reducing sludge volume, enabling the recycling of process water and dividing effluent streams to be treated separately with better efficiency. One of such innovative active abiotic techniques is electrocoagulation (EC).

Electrocoagulation is one of the electrochemical methods used in wastewater treatment. The other methods include electroflotation, electrooxidation and electrodecantation [13]. Currently, all of these methods are under development, and eventually they are aiming at replacing conventional technologies that require an addition of chemicals and even higher energy consumption [14].

Electrocoagulation is based on the application of an electric current to destabilise suspended, emulsified or dissolved contaminants in a solution. The simplest construction of an 
electrocoagulation reactor is an electrolytic cell with one anode and one cathode [15]. The anode provides metal ions to the system, while the cathode releases hydrogen gas. During electrocoagulation, metal ions are dissolved electrically from electrodes, generating coagulants in situ [16].

Among the advantages of EC are its comparatively low investment and maintenance costs, lower, comparing to other treatment techniques, sludge production and the possibility to operate by solar energy [14]. Moreover, EC, when compared to chemical coagulation, benefits from the avoidance of harmful anions added during the treatment, operation at wider $\mathrm{pH}$ range and more stable flocks that allow the possible separation by settling $[17,18]$. Finally, compared to other chemical methods, during electrocoagulation, effluent with a lower total dissolved solids (TDS) content is produced, and that leads to a reduction in the further water recovery costs [19].

The electrodes or conductive metal plates can be made of the same or different materials [15] and can be arranged in a mono-polar or bipolar mode [16]. The electrode materials commonly used in electrocoagulation processes are iron or aluminium, and titanium has also been mentioned [19]. Furthermore, the application of graphite plates, copper, zinc [20] and dimensionally stable anodes (DSA) made of a thin layer of noble metal oxides on titanium substrate [16] has been reported. Most commonly, Al and Fe ions are used in the electrocoagulation processes due to their trivalent forms [21] and the low solubility of their hydroxides [22].

The behaviour of electrodes in different electrolytes has a pivotal role in the formation of a passive oxide film on the anode. The passivation of the anode leads to an increase in the applied potential and to waste of energy during the electrocoagulation treatment. The dissolution of the passive film on the anode surface may be provoked by the presence of corrosive species (e.g. chloride) $[23,24,25]$. In the case of sulfate presence, the desired ratio of $\left[\mathrm{Cl}^{-}\right] /\left[\mathrm{SO}_{4}{ }^{2-}\right]$ should be around 0.1 to ensure a sixfold decrease in the applied voltage and the breakage of the passive film [25].

In addition, the application of electrodes with rough surfaces and frequent current reversals are suggested for the efficient dissolution of the anode [23].

Besides the material of the electrodes, there are other parameters that affect the EC process, such as the reactor design, electrode type, arrangement, current density, operation time, $\mathrm{pH}$ and temperature $[16,26]$. The lack of information on sulfate removal by EC requires detailed laboratory-scale studies before its application on the pilot and industrial scales.

EC as a treatment technique of mining waters is gaining attention due to its successful application for the removal of other typical mining waters contaminants, such as nitrate, sulfate, cyanide, toxic metals, etc. [27-34]. The treatment of mining waters by batch electrocoagulation has been recently studied by Nariyan et al. [35,36]. Mamelkina et al. reported on continuous electrocoagulation concept development for sulfate removal [37]. Del Ángel et al. have conducted electrocoagulation experiments by using aluminium electrodes, and they achieved $53 \%$ of sulfate removal from the drainage from an abandoned 
mine in Guanajuato, Mexico [38]. Radic et al. report over $86 \%$ removal efficiency of sulfate from acid mine drainage with combined $\mathrm{CaO} /$ electrocoagulation treatment [12]. However, the data regarding sulfate removal was reported without detailed information about the processes involved in EC and the parameters affecting the sulfate removal.

Electrocoagulation treatment of sulfate and mechanisms of contaminant removal during the process are rarely studied. Without knowledge on sulfate removal as one of the main components of mining waters it is hard to conclude about the suitability of electrocoagulation to treat mining waters. To fulfil the gap and create the whole picture about mining water treatment by electrocoagulation, there is an acute need to evaluate the suitability of electrocoagulation as a sulfate removal technology.

This paper is dedicated to the investigation of the removal efficiency of sulfate from synthetic mining water depending on the applied current, the initial $\mathrm{pH}$ and the initial sulfate concentration in the solution. The aim of the study is to examine the suitability of treating sulfate-rich waters with electrocoagulation. In addition, the comparison of process performances using iron and aluminium electrodes is provided.

\section{Materials and Methods}

\subsection{Materials}

Synthetic sulfate-rich waters were prepared in order to analyse the removal of sulfate by electrocoagulation. The synthetic water composition was proposed based on the discussions with industrial partners, literature review and public reports available from mines. Synthetic waters contained $\mathrm{SO}_{4}{ }^{2-}, \mathrm{NO}_{3}{ }^{-}, \mathrm{Cl}^{-}, \mathrm{Cu}^{2+}, \mathrm{Ni}^{2+}, \mathrm{Zn}^{2+}, \mathrm{NH}_{4}{ }^{+}$. Sulfate values were chosen based on the average sulfate concentration in Finnish and Swedish mines. Extreme cases were not taken into account. The stock solutions with a sulfate concentration of 1,000, 2,000 and 3,000 $\mathrm{mg} / \mathrm{L}$ were prepared by using $\mathrm{Na}_{2} \mathrm{SO}_{4}, \mathrm{NaNO}_{3}, \mathrm{NaCl}, \mathrm{CuSO}_{4}, \mathrm{NiSO}_{4}, \mathrm{ZnSO}_{4}$ and $\mathrm{NH}_{4} \mathrm{Cl}$ (Merck $\mathrm{KGaA}$ ). The $\mathrm{pH}$ of the solutions was adjusted to a desired level by either $0.1 \mathrm{M} \mathrm{NaOH}$ (Merck $\mathrm{KGaA}$ ) or $0.1 \mathrm{M} \mathrm{HCl}$ (Merck KGaA), depending on the conditions in each test. $\mathrm{NaCl}$ was added to prevent the quick passivation of the anode. The amount of $\mathrm{NaCl}$ required was calculated according to the expression $\left[\mathrm{Cl}^{-}\right] /\left[\mathrm{SO}_{4}{ }^{2-}\right]=0.1$. All of the chemicals were of analytic grade, used without further purification and supplied by Merck KGaA, Germany. The conductivity of the solution was measured and reported on without any adjustments.

\subsection{Experimental equipment and procedure}

Electrochemical tests were performed in a jacketed Plexiglas-reactor (Fig. 1). The treated volume of sulfate-rich water was $1,000 \mathrm{ml}$. The electrochemical cell consisted of four iron or aluminium electrodes connected to the power source by using a monopolar arrangement. The electrode dimensions were $6 \times 7 \mathrm{~cm}$ and the electrode surface area was $84 \mathrm{~cm}^{2}$ per plate (two sides), resulting in $168 \mathrm{~cm}^{2}$ of total anode area. The gap between the electrodes was 10 $\mathrm{mm}$. Constant current was maintained by using laboratory power supply (PS 3005). 


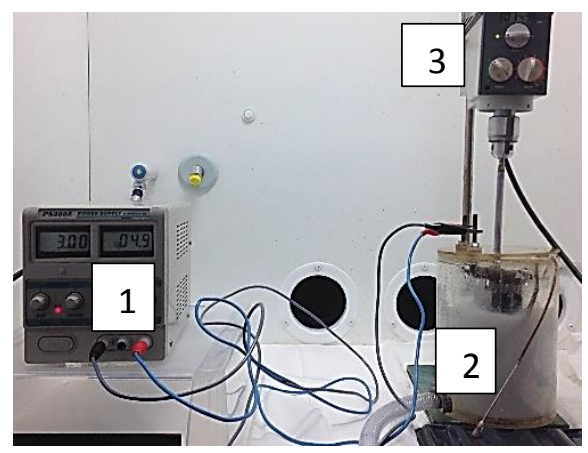

Figure 1. Picture of the experimental setup taken during the EC-test with aluminium electrodes at 3A: (1) power supply, (2) electrochemical cell, (3) mixer

The applied current during EC-treatment with iron electrodes was $1 \mathrm{~A}\left(6 \mathrm{~mA} / \mathrm{cm}^{2}\right), 2 \mathrm{~A}(12$ $\left.\mathrm{mA} / \mathrm{cm}^{2}\right)$ and $3 \mathrm{~A}\left(18 \mathrm{~mA} / \mathrm{cm}^{2}\right)$. Preliminary tests were also performed at range 0.1 to $5 \mathrm{~A}$, however, the noticeable sulfate removal was observed at applied current form 1 to $3 \mathrm{~A}$. Tests with aluminium electrodes were performed at $3 \mathrm{~A}$ and $5.3 \mathrm{~A}\left(31 \mathrm{~mA} / \mathrm{cm}^{2}\right)$. The first three experiments were conducted at a current of $3 \mathrm{~A}$ providing the same current density as in the case of using iron electrodes. The rest of the experiments were conducted at a current of 5.3 A resulting in the same amount of solids formed as in the case of using iron electrodes at a current of $3 \mathrm{~A}$. A plastic curved blade turbine was used to provide proper mixing of the treated solution during each test at a speed of $200 \mathrm{rpm}$, which corresponded to the tip speed of 0.84 $\mathrm{m} / \mathrm{s}$. Treatment over $5 \mathrm{~h}$ makes the technology less competitive, leads to high energy consumption and increase the amount of solids formed. The pre-treatment of iron and aluminium electrodes was performed with a $10 \%$ and $4 \% \mathrm{HCl}$ acid solution, respectively, and after treatment they were rinsed with tap- and distilled water before each run.

A sample of $20 \mathrm{ml}$ was taken with a syringe from the centre part of the reactor once per hour. Straight after the sample was taken, $10 \mathrm{ml}$ were filtered with a $0.45 \mu \mathrm{m}$ syringe filter to enable particle separation, and for the rest of the sample, $\mathrm{pH}$ and conductivity measurements were performed.

\subsection{Design of experiments}

The experiments with iron electrodes were performed according to the $3^{3}$-full factorial design [39]. This was then supplemented with four repetitions of central point and two repetitions of corner points with the minimal and maximal values of the factors thereby totaling a total of 35 experiments. Independent factors were the initial $\mathrm{pH}$ of the solution, the initial concentration of sulfate ions in the solution and the current applied to the system. The experimental conditions for EC-tests with iron electrodes as well as the initial concentrations of water contaminants are given in Table 1 . Six additional experiments with aluminium electrodes were performed to study the influence of electrode material on sulfate removal. The experiment with aluminium electrodes were only performed at the experimental conditions that favoured the highest removal of sulfate using iron electrodes. 
Table 1. Mining water content and experimental conditions used during EC-treatment with iron electrodes

\begin{tabular}{|l|ccc|}
\hline \multicolumn{1}{|c|}{ Parameters } & \multicolumn{3}{c|}{ Levels } \\
\hline Current, I (A) & 1 & 2 & 3 \\
Initial pH & 4 & 7 & 10 \\
Initial concentration, (mg/L) & & & \\
$\mathrm{SO}_{4}^{2-}$ & 1,000 & 2,000 & 3,000 \\
$\mathrm{NO}_{3}{ }^{-}$ & 20 & 40 & 60 \\
$\mathrm{Cu}^{2+}$ & 2 & 5 & 8 \\
$\mathrm{Zn}^{2+}$ & 5 & 10 & 15 \\
$\mathrm{Ni}^{2+}$ & 2 & 5 & 8 \\
$\mathrm{Cl}^{-}$ & 100 & 200 & 300 \\
$\mathrm{NH}_{4}^{-}$ & 10 & 20 & 30 \\
\hline
\end{tabular}

The initial $\mathrm{pH}$ was selected to study the effect of $\mathrm{pH}$ on the efficiency of the electrocoagulation process and to observe the differences between the initial and final $\mathrm{pH}$. The initial concentration of sulfate ions was selected to investigate the efficiency of the electrocoagulation process within the high concentration ranges of sulfate, as concentrations up to $500 \mathrm{mg} / \mathrm{L}$ had been studied previously [22]. Moreover, sulfate concentration in mining waters is an important factor due to its variation from one to tens of thousands of milligrams per litre [1]. The applied current controls the electrochemical reactions occurring on the electrode surface and results in the amount of solids formed during the process.

The measured responses were the residual concentration of sulfate ions in the solution, the final $\mathrm{pH}$ of the solution, conductivity and the mass of electrodes. Based on the collected data, the removal efficiency of sulfate, the weight loss of electrodes and $\mathrm{pH}$ changes during treatment were calculated.

\subsection{Analysis procedure}

The sulfate concentrations were measured with ion chromatography by using Dionex ICS1100 equipped with autosampler Dionex AS-DV. The samples were diluted prior the analyses with an automated laboratory dilutor Hamilton Microlab 500 series. Amounts of iron and aluminium were evaluated by weighting the electrodes before and after each test using the laboratory analytical scales. The $\mathrm{pH}$ was controlled by $\mathrm{pH}$ meter WTW $\mathrm{pH} 304 \mathrm{i}$ and conductivity was measured with Labor-Konduktometer 703.

\section{Results and Discussion}

\subsection{Summary of the laboratory results}


Synthetic mining waters were treated by electrocoagulation in a $1 \mathrm{~L}$ batch reactor using iron and aluminium electrodes. The influence of EC operating parameters on sulfate removal was investigated. A summary of the main results obtained during the EC-tests with iron and aluminium electrodes are given in Table 2 and Table 3, respectively.

Table 2. Removed sulfate and final $\mathrm{pH}$-values solution during EC-tests with iron electrodes at different applied currents, initial $\mathrm{pH}$ and concentrations

\begin{tabular}{|c|c|c|c|c|c|c|c|}
\hline \multirow{3}{*}{ Initial pH } & \multirow{3}{*}{$\begin{array}{c}\text { Concentration, } \\
\mathrm{mg} \backslash \mathrm{I}\end{array}$} & \multicolumn{6}{|c|}{ Applied current } \\
\hline & & \multicolumn{2}{|c|}{$1 \mathrm{~A}$} & \multicolumn{2}{|c|}{$2 \mathrm{~A}$} & \multicolumn{2}{|c|}{$3 \mathrm{~A}$} \\
\hline & & $R, \%$ & $p H$ fin & $R, \%$ & $p H$ fin & $R, \%$ & pH fir \\
\hline $\mathrm{pH} 4$ & \multirow{3}{*}{1,000} & 7 & 11.27 & 10 & 11.69 & 24 & 10.57 \\
\hline $\mathrm{pH} 7$ & & 10 & 11.34 & 29 & 11.73 & 28 & 11.17 \\
\hline $\mathrm{pH} 10$ & & 10 & 11.31 & 38 & 11.84 & 54 & 11.78 \\
\hline $\mathrm{pH} 4$ & \multirow{3}{*}{2,000} & 16 & 11.89 & 25 & 11.97 & 21 & 11.95 \\
\hline $\mathrm{pH} 7$ & & 2 & 10.98 & 35 & 12.01 & 31 & 11.96 \\
\hline $\mathrm{pH} 10$ & & 10 & 11.64 & 37 & 12.17 & 40 & 11.96 \\
\hline $\mathrm{pH} 4$ & \multirow{3}{*}{3,000} & 1 & 10.97 & 24 & 12.16 & 51 & 12.4 \\
\hline $\mathrm{pH} 7$ & & 2 & 11.22 & 33 & 12.21 & 27 & 10.02 \\
\hline $\mathrm{pH} 10$ & & 2 & 11.17 & 27 & 12.14 & 43 & 12.26 \\
\hline
\end{tabular}

Table 3. Removed sulfate and final pH-values solution during EC-tests with aluminium electrodes at different applied currents, initial $\mathrm{pH}$ and concentrations

\begin{tabular}{|c|c|c|c|c|c|}
\hline \multirow{3}{*}{ Initial $\mathrm{pH}$} & \multirow{3}{*}{$\begin{array}{c}\text { Concentration, } \\
\mathrm{mg} \backslash \mathrm{I}\end{array}$} & \multicolumn{4}{|c|}{ Applied current } \\
\hline & & \multicolumn{2}{|c|}{$3 \mathrm{~A}$} & \multicolumn{2}{|c|}{$5.3 \mathrm{~A}$} \\
\hline & & $R, \%$ & $p H$ fin & $R, \%$ & pH fin \\
\hline $\mathrm{pH} 4$ & \multirow{2}{*}{1,000} & 7 & 9.99 & - & - \\
\hline $\mathrm{pH} 10$ & & 8 & 10.63 & 10 & 10.81 \\
\hline $\mathrm{pH} 4$ & \multirow{2}{*}{3,000} & 3 & 9.95 & - & - \\
\hline $\mathrm{pH} 10$ & & 4 & 9.94 & 1 & 10.36 \\
\hline
\end{tabular}

Presented data make it already possible to establish some general relationships observed during the systematic studies on sulfate removal. For instance, the removal of sulfate increases with the increase in applied current. Another finding is the utilisation of iron electrodes for more efficient sulfate removal at the studied concentration ranges. Moreover, the final $\mathrm{pH}$ of the treated solutions was caustic regardless the initial $\mathrm{pH}$ and electrode material. The detailed discussion about the effects of applied current, initial $\mathrm{pH}$ and concentration using iron electrodes applying $3^{3}$-full factorial design is provided in sections 3.2 to 3.3. Sections 3.4 corresponds to the effect of electrode material on sulfate elimination and section 3.5 provides information about the repeatability of the experiments.

3.2. Effect of applied current 
The applied current is one of the most significant factors affecting the electrocoagulation process. This parameter has a significant effect on the dissolution of electrodes, the energy consumption of the process, the change in $\mathrm{pH}$ and conductivity as well as the amount of solids generated $[16,26,29]$. In this study, the experiments with iron electrodes were carried out at three different currents, namely 1,2 and $3 \mathrm{~A}$, tests were performed according to the statistical design of experiments. It was observed that increasing the current from 1 to $3 \mathrm{~A}$ increased the removal of sulfate. A summary of the EC performance in sulfate removal at different currents and various initial sulfate concentrations for initial pH 10 are shown in Fig. 2. The maximum removal efficiencies were $16 \%, 38 \%$ and $54 \%$, respectively, at 1,2 and $3 \mathrm{~A}$, influenced also by the initial concentration. In case of iron electrodes, better removal at higher currents is likely because of the more intensive release of iron ions from the anode surface, resulting in the formation of greater amount of insoluble iron precipitates. Among the possible precipitates with the presence of sulfate in electrolyte are $\mathrm{Fe}_{3} \mathrm{O}_{4}, \alpha \mathrm{FeO}(\mathrm{OH})$, $\gamma \mathrm{FeO}(\mathrm{OH}), \mathrm{FeSO}_{4}(\mathrm{OH})$ and positively charged iron hydroxides [31,40,41]. Thus, higher removal may occur due to the more efficient enmeshment of sulfate in iron oxide and hydroxide and possible charge neutralisation by the excess amount of positively charged iron ions. Other researchers have observed the enmeshment of sulfate ions in porous metal precipitates [22]. Moreover, the adsorption on the precipitates and charge neutralisation as a removal mechanism for other anions have been investigated by several researchers [29,32,42].

Results obtained using $3^{3}$-full factorial design allow to conclude that the highest removal efficiency with iron electrodes was achieved at different combinations of factors at various initial sulfate concentrations; however, the main parameter in the process was the applied current. Thus, highest sulfate removal efficiencies were registered at $3 \mathrm{~A}$ regardless the changes in initial concentration and $\mathrm{pH}$.

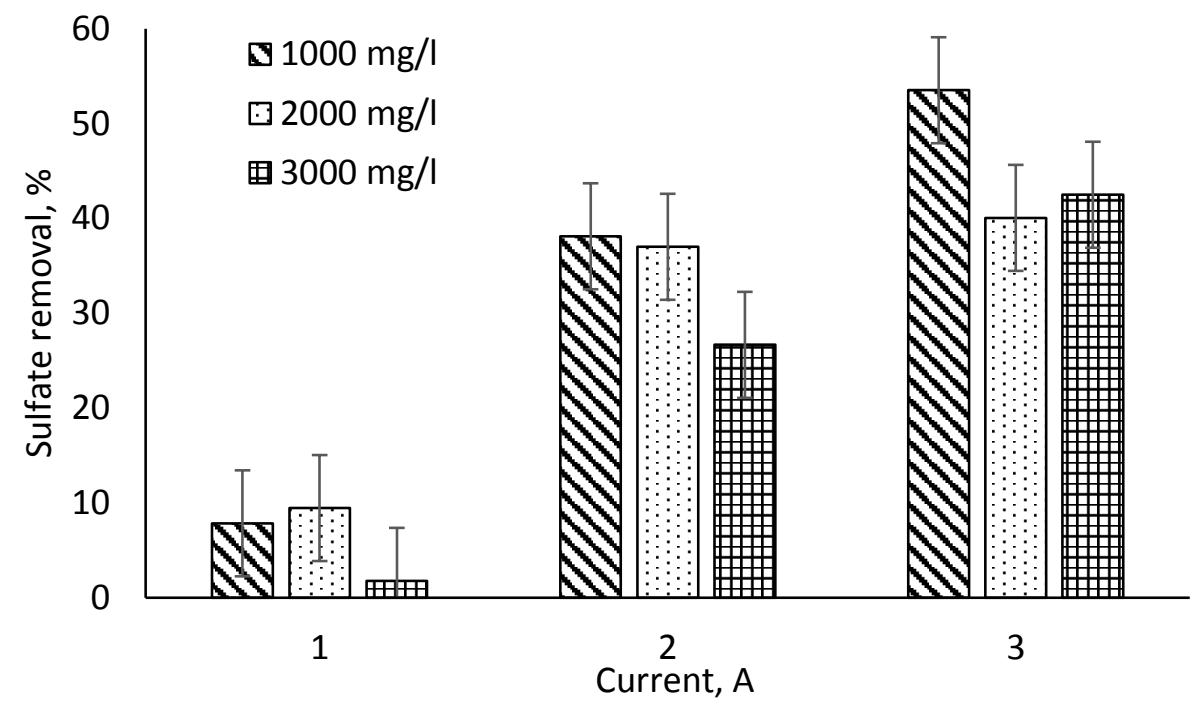


Figure 2. EC-process performance in sulfate removal at different currents and initial sulfate concentrations for initial $\mathrm{pH} 10$, iron electrodes

The highest removal efficiencies for the solutions with sulfate concentrations 1,000, 2,000

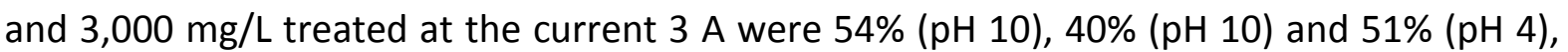
respectively. Based on the difference in the removal efficiencies, it may be concluded that other operating parameters, such as initial $\mathrm{pH}$ and sulfate concentrations affect the performance of EC-treatment of sulfate-rich solutions.

\subsection{Effect of initial $\mathrm{pH}$ and concentration}

The $\mathrm{pH}$ as one of the parameters affecting the EC-process is mainly responsible for speciation and solubility of metal oxides and hydroxides as well as contaminant removal mechanisms. Effect of solution $\mathrm{pH}$ on the performance of EC-process with iron electrodes was evaluated at various initial $\mathrm{pH}$-values 4,7 and 10 using statistical design of experiments. The $\mathrm{pH}$ profile in Fig. 3 shows that after 1 hour of treatment at current $3 \mathrm{~A} \mathrm{pH}$ was around 11.2 regardless of the initial $\mathrm{pH}$ of the solution. This indicates that after 1 hour, electrocoagulation treatment of sulfate took place at base conditions. The upward trend is typical for final $\mathrm{pH}$ with an increase in the current [32]. During the first hour of treatment the initial $\mathrm{pH}$ changed dramatically, and the changes in $\mathrm{pH}$ varied inversely to the increase in the initial $\mathrm{pH}$. A sharp increase in $\mathrm{pH}$ for low initial $\mathrm{pH}$ and comparatively slight change in $\mathrm{pH}$ for high initial $\mathrm{pH}$ was also observed by irdemez et al. [43]. The increase in pH during the EC-treatment has been explained in terms of $\mathrm{OH}$ radical evolution from the cathode and water oxidation at the anode [32]. Moreover, rapid changes from $\mathrm{pH} 4$ to $\mathrm{pH}$ over 11 is explained by faster production and

slower consumption of $\mathrm{OH}$ radicals. The stabilisation of $\mathrm{pH}$ around 11 is likely because of the buffering effect of the iron oxides/hydroxides mixture.

The removal efficiencies of sulfate for the solution containing $3,000 \mathrm{mg} / \mathrm{L}$ of sulfate treated under the current of $3 \mathrm{~A}$ with varying $\mathrm{pH}$ values are shown in Fig. 3. According to the results shown in Fig. 3, poor sulfate removal was observed after the first hours of treatment, but the sulfate started to be removed significantly after two hours of treatment when $\mathrm{pH}$ stabilised at about 12 and the calculated amount of generated solids was $9 \mathrm{~g} / \mathrm{l}$. The high removal efficiency at low $\mathrm{pH}$ seems to be promising for the industrialisation of the method, as it is not necessary to adjust the initial $\mathrm{pH}$ of mine water, or it requires just slight adjustment to obtain partial removal of sulfate. 


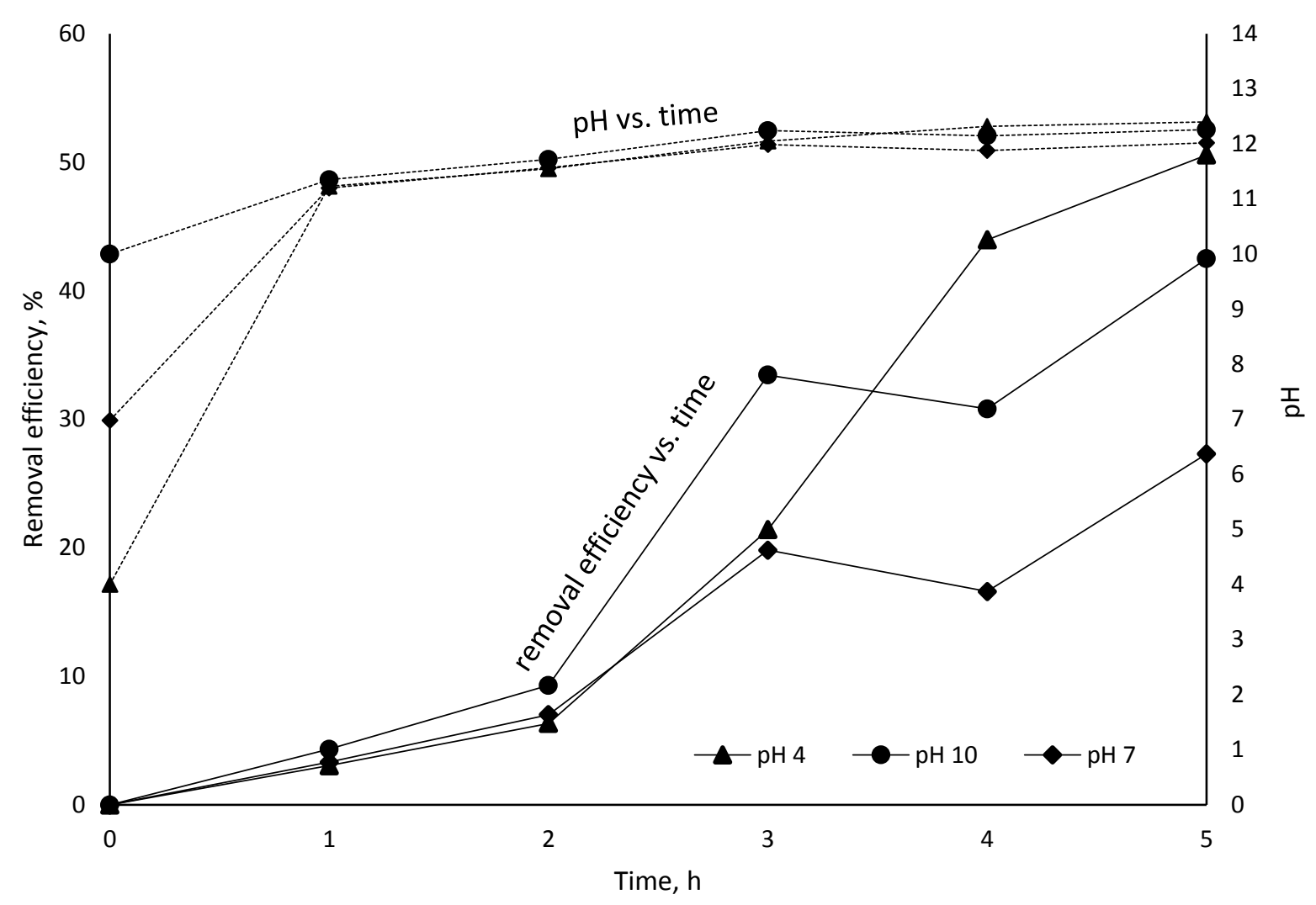

Figure 3. Variation of removal efficiency and $\mathrm{pH}$ of electrocoagulation-treated samples as a function of time at $\mathrm{C}=3,000 \mathrm{mg} / \mathrm{L}$, current $3 \mathrm{~A}$, iron electrodes

Another parameter influencing the removal rate during the EC is initial concentration of the contaminants. To study this phenomenon, experiments with initial sulfate concentrations of $1,000,2,000$ and $3,000 \mathrm{mg} / \mathrm{L}$ and initial $\mathrm{pH}$ values 4,7 and 10 were performed. As an example the relationships between removal efficiency of sulfate and treatment time at $\mathrm{pH} 10$ is plotted in Fig. 4. The observations make it possible to conclude that an increase in initial sulfate concentration results in a lower removal of sulfate. A general decreasing trend in sulfate removal with the initial increasing sulfate concentration at the range of $1,000-3,000 \mathrm{mg} / \mathrm{L}$ is in agreement with earlier reported studies on sulfate removal from synthetic waters with sulfate concentrations varying from 100 to $500 \mathrm{mg} / \mathrm{L}$ [22]. Such a behaviour may be explained by the lower concentration of iron-coagulant required for the removal of sulfate at lower initial concentrations. The content of synthetic mining waters, especially the [Cl-]/[SO42-] ratio, may also affect the process efficiency [25]. 


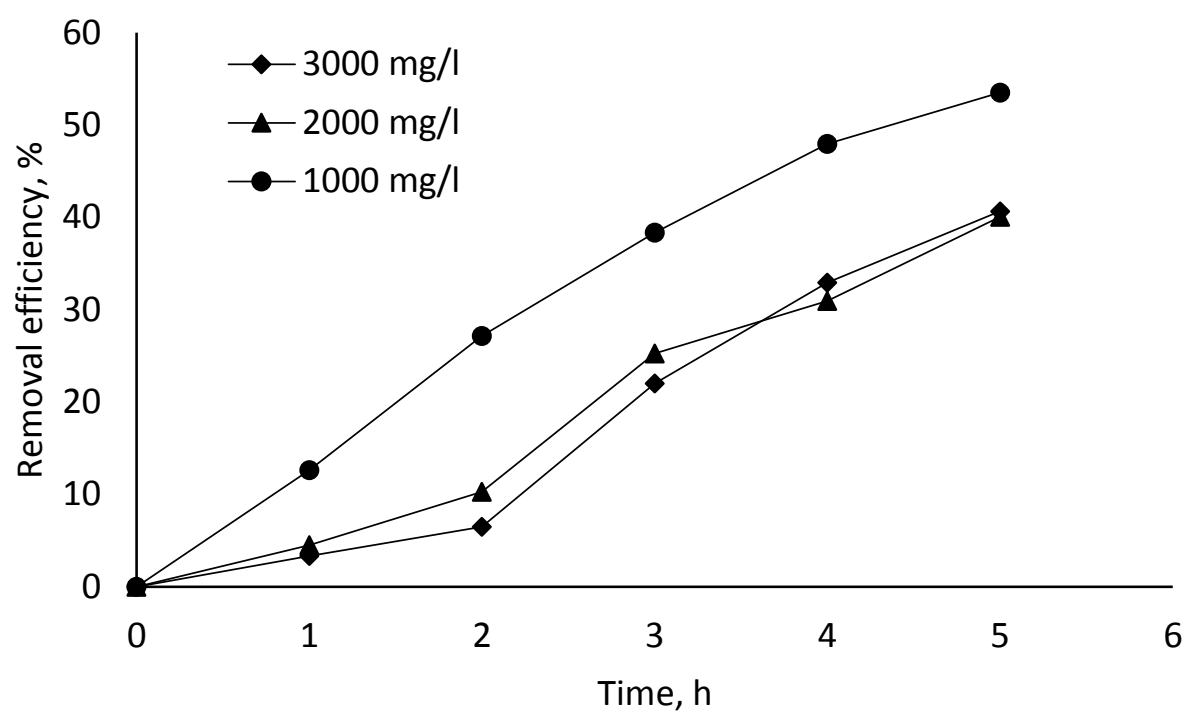

Figure 4. Effect of the initial sulfate concentration on the final sulfate removal of electrocoagulation-treated samples at $\mathrm{pH} 10$, current $3 \mathrm{~A}$, iron electrodes

According to the results with iron electrodes, the highest sulfate removal of $54 \%$ was achieved when the applied current was $3 \mathrm{~A}$, the initial $\mathrm{pH}$ of the solution was 10 , and the initial sulfate concentration in the solution equalled $1,000 \mathrm{mg} / \mathrm{L}$. The highest sulfate removal from the solution with the initial sulfate concentration $3,000 \mathrm{mg} / \mathrm{L}$ was $51 \%$ at the applied current of $3 \mathrm{~A}$ and the initial $\mathrm{pH}$ of 4 . At a current of $2 \mathrm{~A}$, the highest removal efficiency achieved was $38 \%$ at $\mathrm{pH} 10$ for the initial sulfate concentration 1,000 mg/L.

The initial water conductivity was mainly affected by the initial concentration of studied contaminants. It equalled 2.27, 4.23 and $6.20 \mathrm{~ms} / \mathrm{m}$, respectively, to the change in concentration from $1,000 \mathrm{mg} / \mathrm{L}$ to $3,000 \mathrm{mg} / \mathrm{L}$. However, the final conductivity of the ECtreated samples depended greatly on the applied current, and consequently on the presence of iron and other ions in the solution. A higher applied current led to higher change in water conductivity during the EC-process. An increase in conductivity during anion removal by EC is also reported and explained by Kumar et al. and Moussavi et al. [17,33]. Vepsäläinen et al. observed a decrease in conductivity with the increase of current during EC-experiments with mechanically treated water in a paper mill [18].

\subsection{Effect of electrode materials}

Electrode material in EC is mainly responsible for the amount and type of metal ions in the solution, coagulation efficiency and process costs. In this study, iron and aluminium electrodes were tested and the loss of electrode weight was investigated during the experiments. The obtained results presented in Fig. 5 show that the generation of iron and aluminium from the anodes was repeatable and affected by the applied current. The amount of generated solids increased proportionally to the current. 
Theoretical and experimental amounts of generated iron were compared at currents 1, 2 and 3A. Experimentally generated amounts of iron at different currents correlated with the theoretical amounts based on the calculation (Faraday's law) when the number of electrons transferred ( $z$ ) equalled to 2 , while with $z=3$ excess formation of iron of up to $50 \%$ during the experiments could be observed. The literature reports on iron dissolution of around $100 \%$ [16] or lower than $100 \%$ [44]. According to this, the formation of $\mathrm{Fe}^{2+}$ was expected during the present EC-experiments. Moreover, the literature proposes various mechanisms of iron generation and solids formation during the EC-process. A detailed summary is given by [40].

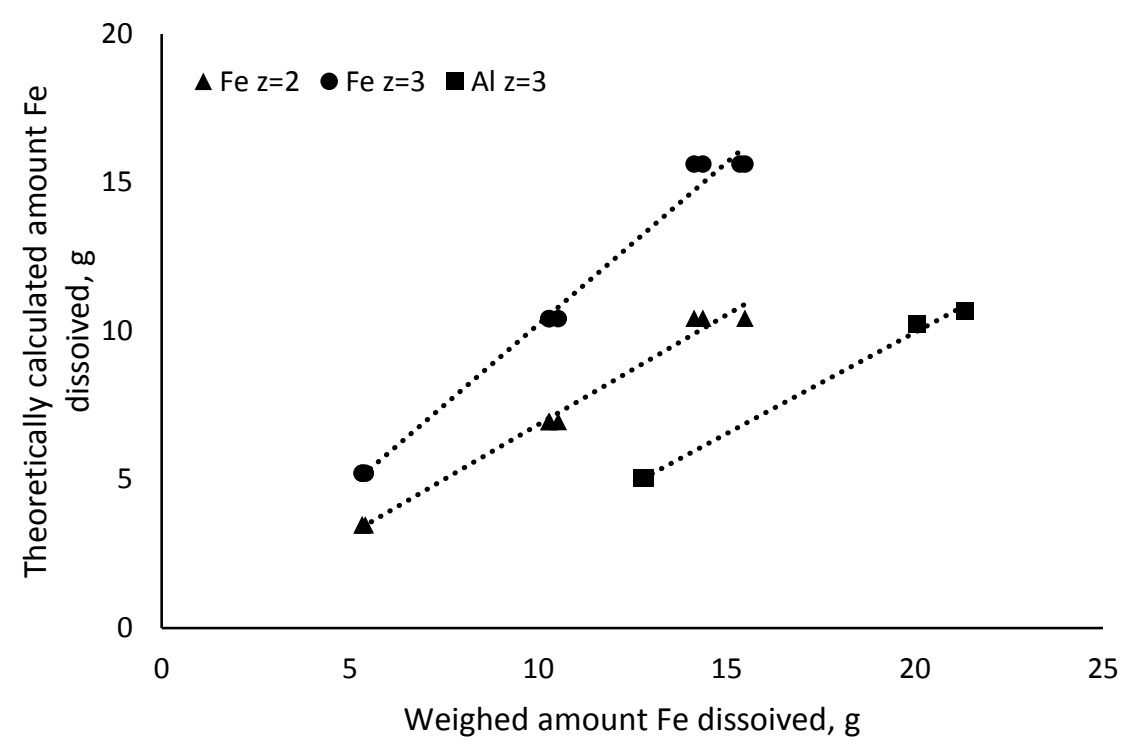

Figure 5. Correlation between theoretically calculated and experimentally obtained amount of iron and aluminium generated at various currents during the

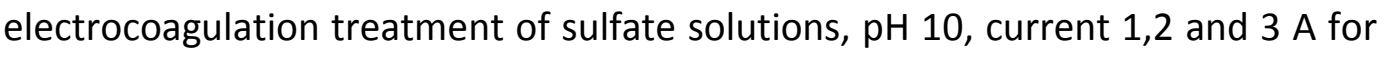
$\mathrm{Fe}, 3$ and $5.3 \mathrm{~A}$ for $\mathrm{Al}$

Experimental amounts of generated aluminium were two times higher than those theoretically predicted. Such a behaviour can be explained by a chemical attack of aluminium cathode induced by hydrogen evolution resulting in a significant contribution to the total amount of aluminium released. For example, Linares-Hernandez et. al. reported of an excess of $50 \%$ between the calculated and measured concentrations of $\mathrm{Al}^{3+}$ [45]. According to Mouedhen et al., the current efficiency of aluminium dissolution was about $175 \%$ [24]. The exceeded experimental amounts of generated aluminium can be additionally explained by the presence of chloride in the mining waters. In this case, operating at relatively high current densities, chloride acts as a pitting agent promoting the breakage of the passive layer and increasing the dissolution efficiency of the aluminium electrodes [46].

The effect of electrode materials on sulfate removal was studied using two different approaches. Based on the results obtained during the EC using iron electrodes, the most suitable conditions for the highest removal of sulfate within the range of studied parameters 
were chosen. According to these results, EC-tests using aluminium electrodes were performed, firstly, by applying the same current densities and, secondly, by generating the same amount of solids. The results of the EC-process performance, in accordance with the different electrode materials, are shown in Fig. 6.

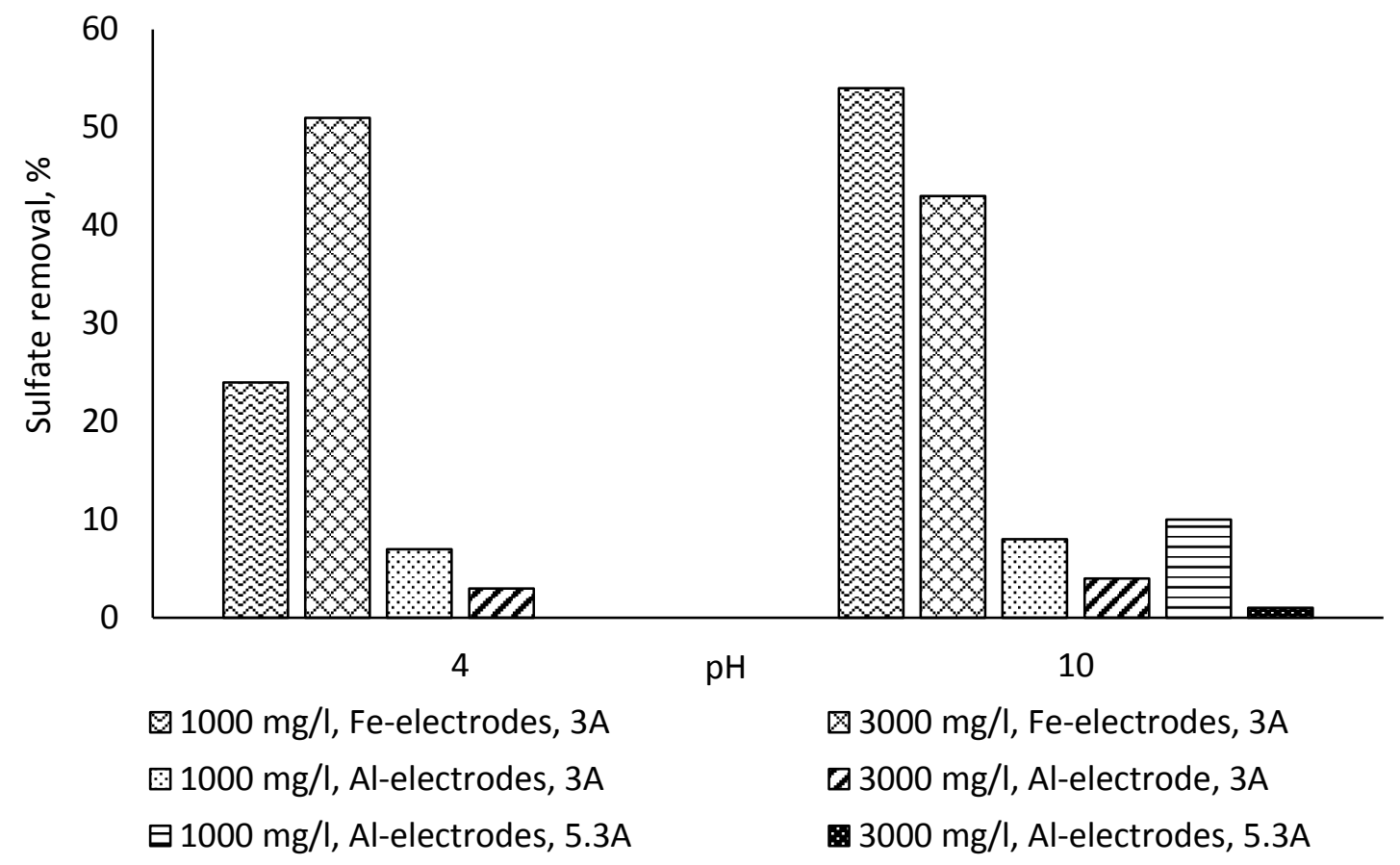

Figure 6. Comparison of sulfate removal from tested waters treated by EC using aluminium and iron electrodes at chosen experimental conditions

It can be seen in Fig. 6 that the application of iron electrodes resulted in more efficient sulfate removal with the highest of $54 \%$, while for aluminium electrodes the highest removal efficiency obtained was $10 \%$. The reason for the poor sulfate removal could be the final $\mathrm{pH}$ of the solution, which was around 10. The most probable species that are responsible for electrocoagulation efficiency with aluminium are polymeric hydroxoaluminium ions and the aluminium hydroxide precipitates [25,47]. At a pH higher than 9 , the formation of aluminium precipitates decreases [44] and the formation of negatively charged hydroxoaluminium ions is expected [23] making the charge neutralisation of negatively charged sulfate impossible. Poor sulfate removal using aluminium electrodes at a $\mathrm{pH}$ higher than 10 is in accordance with the results reported by earlier researchers [22].

In general, the partial removal of sulfate ions from the solution can be explained in terms of the good solubility of aluminium and iron sulfate in aqueous media, electrocoagulation operation at caustic conditions and low amount of positively charged ions to neutralise the charge of negative bivalent ions.

3.5. Repeatability of experiments 
Repeatability refers to the variation in the results obtained from repeated experiments on the same subject under identical conditions $[48,49]$. The objective is to quantify the agreement of the results obtained by the studied method. Among the reasons to repeat the experiments are the verification of results, data collection for statistical analysis of the results as well as the development of skills of an operator. Good repeatability gives confidence in the quality of the whole data set produced during the research work. To check the repeatability during the electrocoagulation treatment of sulfate-rich solution, four independent experiments were performed. The initial conditions for the repeatability tests were chosen to be the central points with initial sulfate concentration $2000 \mathrm{mg} / \mathrm{L}, \mathrm{pH} 7$ and current $2 \mathrm{~A}$. Tests were performed with the repeatability condition of a measurement meaning that measurements were performed over a short period of time using the same operator, same measuring system and same operating conditions [49].

The behaviour of $\mathrm{pH}$ (Fig. 7a) and sulfate removal efficiency (Fig. 7b) versus time during the repeatability tests is considered. Test 1, Test 2 and Test 3 with iron electrodes were conducted one after the other in three days with totally new iron electrodes used as anodes and cathodes, while Test 4 took place after 11 more experiments performed at different operational conditions.

a.

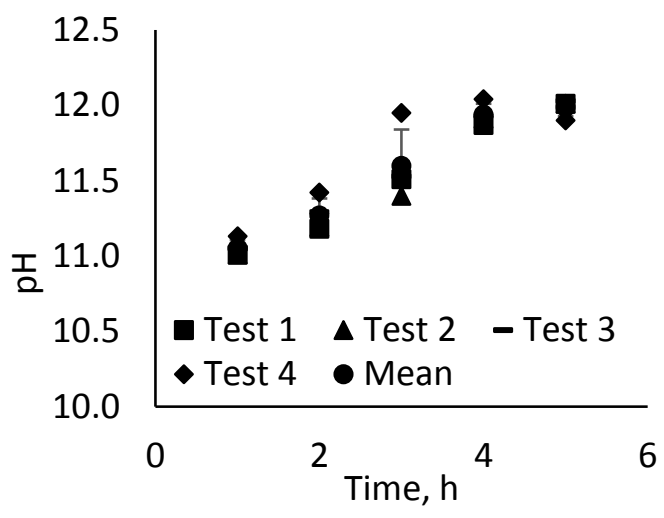

b.

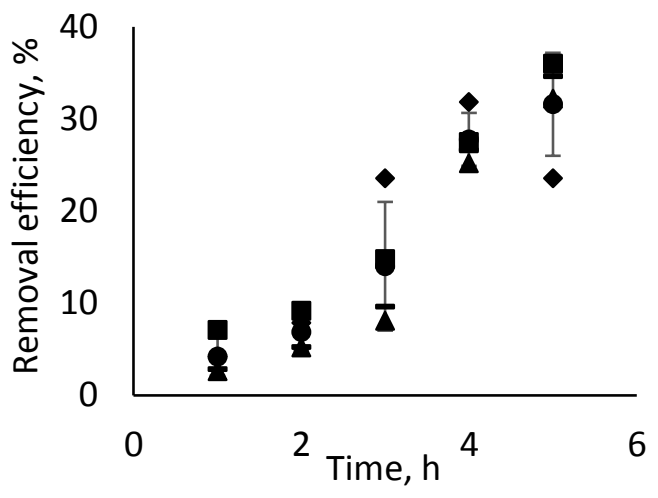

Figure 7. Variation of a) $\mathrm{pH}$ and b) removal efficiency of sulfate, as a function of time obtained during repeated electrocoagulation tests with sulfate solutions at $\mathrm{C}=2000 \mathrm{mg} / \mathrm{L}, \mathrm{pH} \mathrm{7,} \mathrm{current} 2 \mathrm{~A}$, iron electrodes

The results of Test 1, Test 2 and Test 3 were in agreement since the changes in sulfate removal followed the same pattern, and the $\mathrm{pH}$-graphs were repeatable. The obtained results are repeatable over a short period of time. The discrepancy of results for Test 4 after $3 \mathrm{~h}$ of treatment may tell about the poor reproducibility of the results that may be, over an extended period of time, caused by the possible roughness of the electrode surface and thus the increase of electrode's surface area resulting in more efficient iron dissolution already after 3 $\mathrm{h}$ of treatment. 


\section{Conclusion}

The conducted research on the electrocoagulation treatment of sulfate-rich streams has provided an understanding of the phenomenon occurring during the process. The results illustrated that sulfate removal is a current dependent process, and an increment of applied current favours the contaminant removal. However, the contaminant removal was still found to be challenging at higher sulfate concentrations. The highest removal rates were attained with iron electrodes. For most of the experimental conditions, the sulfate removal rate was moderate. Most probably, this happened because of the good solubility of iron and aluminium sulfate, operation of electrocoagulation at base conditions and possible passivation of electrodes in the presence of sulfate in the solution. The electrocoagulation removal mechanism of sulfate was proposed according to the $\mathrm{pH}$ of the treated solution and speciation of solids formed during the process. The removal of sulfate is due to its enmeshment on iron oxides and hydroxides as well as ion charge neutralisation by positively charged iron hydroxocomplexes. Once we have a more detailed explanation of sulfate behaviour during the treatment, electrocoagulation could be considered as a suitable auxiliary process for the removal of sulfate, while treating other compounds, but not the main sulfate treatment technology. In addition to the performed systematic studies, to ensure the suitability of electrocoagulation for sulfate removal the real mining waters should be treated. Potentially, moderate sulfate removal will enable the reuse and recycling of process water and minimise the effect of mining waters on the environment.

\section{Acknowledgements}

This work was performed as part of the Water Conscious Mining (WASCIOUS) project funded by the NordMin - A Nordic Network of Expertise for a Sustainable Mining and Mineral Industry.

\section{References}

[1] Oncel, M.S., Muhcu, A., Demirbas, E., Kobya, M., 2013. A comparative study of chemical precipitation and electrocoagulation for treatment of coal acid drainage wastewater. Journal of Environmental Chemical Engineering. 1, 989-995.

[2] Silva, L.F.O., Wollenschlager, M., Oliveira, M.L.S., 2011. A preliminary study of coal mining drainage and environmental health in the Santa Catarina region, Brazil. Environmental geochemistry and health. 33, 55-65.

[3] Johnson, D.B., Hallberg, K.B., 2005. Acid mine drainage remediation options: a review. Sci. Total Environ. 338, 3-14.

[4] Lottermoser, B.G., 2010. Mine wastes: characterization, treatment and environmental impacts, 3rd ed. Springer, Verlag Berlin Heidelberg. 
[5] Kivi, J., 2014-02-11. Wastewater treatment technologies and water recycling in mining and mineral extraction processes - a literature survey; Jätevedenkäsittelymenetelmät ja veden kierrätys kaivos- ja mineraaliteollisuudessa - kirjallisuustutkimus., $132+16$.

[6] Sánchez-Andrea, I., Sanz, J.L., Bijmans, M.F.M., Stams, A.J.M., 2014. Sulfate reduction at low pH to remediate acid mine drainage. J. Hazard. Mater. 269, 98-109.

[7] Akcil, A., Koldas, S., 2006. Acid Mine Drainage (AMD): causes, treatment and case studies. J. Clean. Prod. 14, 1139-1145.

[8] Simate, G.S., Ndlovu, S., 2014. Acid mine drainage: Challenges and opportunities. Journal of Environmental Chemical Engineering. 2, 1785-1803.

[9] Brasilian Ministry of Environment, 1997. Do lançamento de efluentes líquidos na rede coletora de esgotos. 18.328.

[10] Chilean Ministry of Public Works, 1998. Norma de emision para la regulacion de cantaminantes asociados a las descargas de residuos liquidos a sistemas de alcantarillado.

[11] Tolonen, E., Sarpola, A., Hu, T., Rämö, J., Lassi, U., 2014. Acid mine drainage treatment using byproducts from quicklime manufacturing as neutralization chemicals. Chemosphere. 117, 419-424.

[12] Radić, S., Vujčić, V., Cvetković, Ž., Cvjetko, P., Oreščanin, V., 2014. The efficiency of combined $\mathrm{CaO} /$ electrochemical treatment in removal of acid mine drainage induced toxicity and genotoxicity. Sci. Total Environ. 466-467, 84-89.

[13] Sillanpää, M., Shestakova, M., 2017. Chapter 2 - Electrochemical Water Treatment Methods. , 47-130.

[14] Mollah, M.Y.A., Morkovsky, P., Gomes, J.A.G., Kesmez, M., Parga, J., Cocke, D.L., 2004. Fundamentals, present and future perspectives of electrocoagulation. Journal of Hazardous Material. B114, 199-210.

[15] Emamjomeh, M.M., Sivakumar, M., 2009. Review of pollutants removed by electrocoagulation and electrocoagulation/flotation processes. J. Environ. Manage. 90, 1663-1679.

[16] Chen, G., 2004. Electrochemical technologies in wastewater treatment. Separation and Purification Technology. 38, 11-41.

[17] Kumar, N.S., Goel, S., 2010. Factors influencing arsenic and nitrate removal from drinking water in a continuous flow electrocoagulation (EC) process. J. Hazard. Mater. 173, 528-533.

[18] Vepsäläinen, M., Selin, J., Pulliainen, M., Sillanpää, M., 2007. Combined electrocoagulation and chemical coagulation of paper mill mechanically cleaned water. J Pulp Pap Sci. 33, 233-239.

[19] Mollah, M.Y.A., Schennach, R., Parga, J.R., Cocke, D.L., 2001. Electrocoagulation (EC) - science and application. Journal of Hazardous Material. B84, 29-41.

[20] Gupta, V.K., Ali, I., 2013. Chapter 6 - Water Treatment by Electrical Technologies. In: Gupta, V.K., Ali, I. (Eds.). Environmental Water. Elsevier, pp. 155-178.

[21] Attour, A., Touati, M., Tlili, M., Ben Amor, M., Lapicque, F., Leclerc, J.-., 2014. Influence of operating parameters on phosphate removal from water by electrocoagulation using aluminum electrodes. Separation and Purification Technology. 123, 124-129. 
[22] Murugananthan, M., Raju, G.B., Prabhakar, S., 2004. Removal of sulfide, sulfate and sulfite ions by electro coagulation. J. Hazard. Mater. 109, 37-44.

[23] Mechelhoff, M., Kelsall, G.H., Graham, N.J.D., 2013. Electrochemical behaviour of aluminium in electrocoagulation processes. Chemical Engineering Science. 95, 301-312.

[24] Mouedhen, G., Feki, M., Wery, M.D.P., Ayedi, H.F., 2008. Behavior of aluminum electrodes in electrocoagulation process. J. Hazard. Mater. 150, 124-135.

[25] Trompette, J.L., Vergnes, H., 2009. On the crucial influence of some supporting electrolytes during electrocoagulation in the presence of aluminum electrodes. J. Hazard. Mater. 163, 1282-1288.

[26] Chopra, A.K., Sharma, A.K., Kumar, V., 2001. Overwiew of electrolytic treatment: An alternative technology for purification of wastewater. Archives of Applied Science Research. 2, 191-206.

[27] Bektaş, N., Akbulut, H., Inan, H., Dimoglo, A., 2004. Removal of phosphate from aqueous solutions by electro-coagulation. J. Hazard. Mater. 106, 101-105.

[28] Drouiche, N., Ghaffour, N., Lounici, H., Mameri, M., 2007. Electrocoagulation of chemical mechanical polishing wastewater. Desalination. 214, 31-37.

[29] Kobya, M., Demirbas, E., Dedeli, A., Sensoy, M.T., 2010. Treatment of rinse water from zinc phosphate coating by batch and continuous electrocoagulation processes. J. Hazard. Mater. 173, 326334.

[30] Koparal, A.S., Öğütveren, Ü.B., 2002. Removal of nitrate from water by electroreduction and electrocoagulation. J. Hazard. Mater. 89, 83-94.

[31] Kumar, A., Nidheesh, P.V., Suresh Kumar, M., 2018. Composite wastewater treatment by aerated electrocoagulation and modified peroxi-coagulation processes. Chemosphere. 205, 587-593.

[32] Lacasa, E., Cañizares, P., Sáez, C., Fernández, F.J., Rodrigo, M.A., 2011a. Electrochemical phosphates removal using iron and aluminium electrodes. Chem. Eng. J. 172, 137-143.

[33] Moussavi, G., Majidi, F., Farzadkia, M., 2011. The influence of operational parameters on elimination of cyanide from wastewater using the electrocoagulation process. Desalination. 280, 127133.

[34] Pulkka, S., Martikainen, M., Bhatnagar, A., Sillanpää, M., 2014. Electrochemical methods for the removal of anionic contaminants from water - A review. Separation and Purification Technology. $132,252-271$.

[35] Nariyan, E., Sillanpää, M., Wolkersdorfer, C., 2018. Uranium removal from Pyhäsalmi/Finland mine water by batch electrocoagulation and optimization with the response surface methodology. Separation and Purification Technology. 193, 386-397.

[36] Nariyan, E., Sillanpää, M., Wolkersdorfer, C., 2017. Electrocoagulation treatment of mine water from the deepest working European metal mine - Performance, isotherm and kinetic studies. Separation and Purification Technology. 177, 363-373.

[37] Mamelkina, M.A., Cotillas, S., Lacasa, E., Sáez, C., Tuunila, R., Sillanpää, M., Häkkinen, A., Rodrigo, M.A., 2017. Removal of sulfate from mining waters by electrocoagulation. Separation and Purification Technology. 182, 87-93. 
[38] Del Ángel, P., Carreño, G., Nava, J.L., Martínez, M.T., Ortiz, J., 2014. Removal of arsenic and sulfates from an abandoned mine drainage by electrocoagulation. Influence of hydrodynamic and current density. International Journal of Electrochemical Science. 9, 710-719.

[39] Brereton, R.G., 2007. Applied Chemometrics for Scientists. Appl. Chemometrics for Sci., 1-379.

[40] Lakshmanan, D., Clifford, D.A., Samanta, G., 2009. Ferrous and ferric ion generation during iron electrocoagulation. Environmental Science and Technology. 43, 3853-3859.

[41] Moreno, H.A., Cocke, D.L., Gomes, J.A.G., Morkovsky, P., Parga, J.R., Peterson, E., Garcia, C., 2007. Electrochemical generation of green rust using electrocoagulation. ECS Transaction. 3, 67-78.

[42] Lacasa, E., Cañizares, P., Sáez, C., Fernández, F.J., Rodrigo, M.A., 2011b. Removal of nitrates from groundwater by electrocoagulation. Chem. Eng. J. 171, 1012-1017.

[43] İrdemez, Ş., Demircioğlu, N., Yildiz, Y.Ş., 2006. The effects of pH on phosphate removal from wastewater by electrocoagulation with iron plate electrodes. J. Hazard. Mater. 137, 1231-1235.

[44] Jiménez, C., Sáez, C., Martínez, F., Cañizares, P., Rodrigo, M.A., 2012. Electrochemical dosing of iron and aluminum in continuous processes: A key step to explain electro-coagulation processes. Separation and Purification Technology. 98, 102-108.

[45] Linares-Hernández, I., Barrera-Díaz, C., Roa-Morales, G., Bilyeu, B., Ureña-Núñez, F., 2009. Influence of the anodic material on electrocoagulation performance. Chem. Eng. J. 148, 97-105.

[46] Llanos, J., Cotillas, S., Cañizares, P., Rodrigo, M.A., 2014. Effect of bipolar electrode material on the reclamation of urban wastewater by an integrated electrodisinfection/electrocoagulation process. Water Research. 53, 329-338.

[47] Jiaqian, J., 1988. An anodic passivation of electrocoagulator in the process of water treatment. Water Treatment. 3, 344-352.

[48] Bartlett, J.W., Frost, C., 2008. Reliability, repeatability and reproducibility: Analysis of measurement errors in continuous variables. Ultrasound Obstet. Gynecol. 31, 466-475.

[49] Plesser, H.E., 2018. Reproducibility vs. Replicability: A brief history of a confused terminology. Front. Neuroinformatics. 11. 